\title{
The State and the Limits of Democratization
}

\author{
Wale Are Olaitan \\ Department of Political Science \\ Olabisi Onabanjo University, Ago-Iwoye
}

\begin{abstract}
The paper is about state and democracy in Africa. The author argues that one problem underlying democratization in Africa is the .continuing existence of African states as non-functional and ineffective entities. The fact that African states do not exercise reasonable and effective control over their territory presents uncondusive contexts for democratization.
\end{abstract}

\section{Introduction}

To what extent is the state of critical and central concern in the drama of the limited success and the contradictions characterizing democratic transition in Africa? What are the definitive characteristics of the state's existence in Africa? And how are these characteristics to be addressed as part of a successful strategy for democratic transition in Africa? In what precise manner is the state implicated in the continued shortcomings and deficiencies of the democratization process in Africa and how possible is it to forge a successful process outside the consideration of the contradictory characteristics of the state? These are the questions tackled in this paper as part of an overall review of the process of democratic transition in Africa. The aim is to address the shortcomings of the process and outline concrete remedies to ensure the realization of its goals.

The review here is against the background of the continuing inability of the process of democratic transition in Africa to register concrete improvements in the material, socio-cultural and political life of the people, in spite of the nominal changes visible in the enthronement of civilian governments and the conduct of multi-party elections in many countries in Africa. For the democracy movement in Africa is not just about the prospect of elections and civilian governments and the conduct of multi-party elections in many countries in Africa. For the democracy movement in Africa is not just about the prospect of elections and civilian governments, but more about a protest against the failure of various governments in Africa to 'live up to people's expectations ... including the fulfillment of their basic human needs' (Nzongola-Ntalaja, 1997: 15). It therefore means that there is a need to the move the democratization process in Africa beyond its present limitations toward the full realization of the goals of meeting the people's expectations. 
Yet, the argument is also true that the state is the epitome of the political organization of the modern social formation, such that all other processes, including the democratization process, take place within its context. In which case, it is not illogical to relate the democratization process in Africa and its limitations to the existing context of the state in Africa and seek remedies to these limitations within the same context. And this especially recommends itself in the light of the not-so-desirable existence and functioning of the state in Africa (Ake, 1996; Nzongola-Ntalaja and Lee, 1997), suggesting the need to assess and account for the contributions of the 'inefficient' state in Africa to the limitations of democratic transition as a significant input into the remedying process. However, this would have to be done within the context of a general relationship between the state and democracy.

\section{Of State and Democracy}

It is often recognized that the relationship between the state and democracy is beyond the state providing the context for democratic rule. This is because the existence and nature of the state is taken for granted on the assumption that the state sits atop every modern social formation and therefore provides the context for all activities in the society including democratic rule. The important thing within this argument is simply to see or work out how the democratic ideal is constructed on the structure of the state given that there is no other structure of modem societal organization within which democracy functions. Here the state is no more than a given prop or plank for the construction or functioning of democracy.

Yet, this assumption carries with it the further implication for the specific context that is provided by the state for democracy. For it is also true that the state is a specific form of societal organization that emerged at a point in history and development of the human society, carrying with it specific attributes defining its existence. But it is also in the nature of attributes that their manifestation is a matter of more or less, such that the specific manifestation of a given state is important in the consideration of the context it provides for the organization of its society. This is the sense in which, beyond the consideration of the general characteristics of the state, scholars have had to be concerned with the study of specific states in order to advance particular understanding of the workings of the different states. It is also within this context that Ake (1996) argued that democratization should not be blind to the character of the state as the differing character of states presents different context for the organization of society. While it is true, therefore, that the state generally provides the context for democracy, it is still important to be concerned with the nature of the specific context provided in a given case as basis for adequate understanding of the workings of democracy in any particular society.

But there is even a more fundamental relationship between the state and democracy. Siedentop (1983) argued that the concept of the state' presupposes an individualist model of society'. This is definitely a 
presupposition that carries enormous implication for the existence of the society. For the individual is not just the physical body but a 'type of social role, resting on a set of normative and material preconditions' (Siedentop, 1983). The individual in the context of the state has to understand himself/herself as an individual vis-a-vis others as different from the possession of a physical body. This means that the individual beyond having a physical body rests on a conceptual understanding that manifests in societal role, a role that is also widely acknowledged, suggesting that the individual as a social role is not given, and that the individual does not exist under every and any form of societal organization, but is historically specific to the state.

The value that is crucial to the notion of the individual in this regard is equality. As stated by Siedentop (1983), "without a fundamental (or underlying) equality of status, the social role of the individual ... has no basis. It is only by means of such equality of status, and the shared attributes it contributes to identity, that a person can see himself or herself as one among others". It is to the extent that a person conceives himself/ herself as being of equal status with others that the individual as a social role emerges, different, as already stated, from the possession of physical body. Incidentally, it is the state that provides the basis .for the notion of the individual as a social role based on equality. This is because it is the state, in principle, that entails equal subjection to a supreme authority or power, the sovereign. By definition, the sovereign is that authority or power to which everyone is equally subject. And it is 'by reference to that sovereign that agents can identify themselves as individuals in a society composed of such rather than, say, ... castes or clans' (Siedentop 1983). It thus means that it is through the equal subjection to a sovereign power that individuals are enabled to identify themselves as such, making the state the important guarantor of the individual as a social role.

The implication of this argument is that it is not possible to conceive the individual and its attendant equality of status outside the state; indeed, the emergence of the state is crucial to the development of the individual as a type of social role. This means that the state becomes 'the fulcrum of individual identity' to the extent that it is the existence of the state that makes possible the emergence of the individual in that social capacity. This gives the state a 'basic role in the socializing process' in that its existence helps to guarantee the continuous existence of individual identity and the socialization of new members into that individualist context. In this wise, the state is more than just a passive framework for the existence of the individual, as it actively facilitates that existence through its guarantee of the 'equality' embedded in equal subjection to the sovereign.

If the state is the guarantor and facilitator of the individual identity in society, it is not difficult to see its deep link to democracy. This is because democracy takes its cue essentially from the notion of individual identity. The idea of the participation of every member of the society in the governing process, even if in representative capacity, which underlines 
democratic rule, rests essentially on the notion of equality of the individual which is tied to individual identity. Without prejudice to the number of variants of actual democratic construction, the idea of democracy rests on notion of individual identity which is informed by the equality of status. It therefore means that to the extent that the state is the fulcrum of individual identity which helps to sustain the notion of democracy, to that extent is the state, in a sense, the fulcrum of democracy. This is why democracy is essentially conceived within the context of the state, emphasizing that democracy is possible and achievable only within the same context of the state. The state, as such, is the necessary starting point for any construction of democracy given that the individual identity to sustain democratic construction is possible only within the context of the state.

It is nonetheless possible to point to the existence of states where democracy is not practiced as basis for the attenuation of the link being argued between the state and democracy. But this would be to miss the essence of the point being made here. The argument is not that the existence of the state is sufficient to guarantee democratic construction or rule; rather, the point is that democratic rule is not possible outside the context of the state to the extent that the core ingredient of demoqracy -individual identity - is tied to the existence of the state. This means that whereas more than the state would be required to have successful democratic rule, the non-existence of the state makes the idea of democratic rule essentially inconceivable and non-existence of the state makes the idea of democratic rule essentially inconceivable and non-sustainable. This is the sense in which any meaningful democratic construction would have to be etched on the real structures of a state in existence. A functional state is required to sustain the idea of the individual without which democracy is essentially impossible; that state alone does not make democracy, but democracy is not possible without the state.

Furthermore, the mere existence of individual identity under the aegis of the state is a very important push for democracy even where democratic rule is not the norm as the equality implied in the identity serves to invigorate individuals to ask for reforms and changes that are consistent with the notion of equality and, by extension, democracy. Argues Diedentop (1983):

The laws of the state may ratify or create forms of inequality ... which may seem to run against any connection ... between the state and the idea of equality. But that break is more apparent than real. For the mere existence of a centralized agency to which all are understood as equally subject sustains an awareness in subjects that there is at least one level at which they share an attribute, even if it is only equal subjection to the same authority. That shared attribute, and the sense of a common identity as individuals which it sustains, can easily become the basis for insisting on extending the range of shared attributes. 
The state, properly conceived and functional, therefore, does not just provide a context for democracy, but actively Kelps the cause and course of democracy through individual identity that it provides, which identity necessarily nurtures and sustains democracy. Conversely, the clam our for democracy without the existence of the state and the attendant individual identity is bound to be a mirage as such is necessarily misplaced, lacking in a necessary ingredient for the sustenance of democracy which is the individual identity provided by the state. The state, therefore, is a crucial element in democratic rule, to the extent that it provides a context for it, goat provides a context for it, guar form which democracy springs and gets its sustenance, provides the necessary impetus for democracy by keeping alive the equality of status underpins it, such that democratic rule is not conceivable outside of the context of the state and is feasible only on the basis of the existence of the state. The bottom line is that the link between the state and democracy makes it imperative for the state to be made the essential platform of democratic construction even as it is impossible to realize democratic rule outside of the context of a real, functional state.

\section{On the Nature of the State of Africa}

It is difficult to deny the existence of the state in Africa; but it is much more difficult to affirm its existence. This is because whereas the medley of institutions that exist and function in its name in Africa - the bureaucracy, the armed forces, the prisons etc. makes it impossible to deny its existence, the sheer level of criminality, lawlessness, brigandage and lack of order characterizing such existence calls into question its real meaning. For it is said that the state hinges its existence on the imposition of order by the sovereign, why is it that African countries are characterized largely by lack of order in spite of the existence of the stale? And if it is to be assumed that the state is the epitome of societal organization, investing itself with ultimate power within its territory, how is it to be explained that institutions of the state in Africa find it difficult to enforce rules and guidelines? What is to be said for the existence of a state order in Africa where state officials have elevated involvement in illegal and criminal types of activities to the level of routine acts in the argument of Bayart and others (1999)? Is the existence of a 'criminal state' not a contradiction in terms given that the existence of the state is supposed to put a stop to criminality as a way of life through its imposition of order?

No significant voice, to be sure, denies that what passes for the state in Africa is substantially different from the ideal or even the functional notion of the state. This is because beyond the fact that the state in Africa exists mainly on the strength of its institutions, even these institutions themselves rely majorly on force in their functioning. Yet, it is well recognized that the state, while enjoying a unique power of legitimate use of force, is essentially an institutionalized order, functioning through the substantial acceptance of its rules and regulations in the society. But the state in Africa exhibits a remarkable inability to institutionalize itself 
and claim obedience outside the use offered. This is why Bratton (1989) argued that 'the African state is weak by any conventional measure of institutional capacity'; while Ake (1996) adds that 'the (African) state ... turns on the calculus of strength'.

It is this weakly institutionalized state in Africa that Callaghy described as a 'lame leviathan' to the extent that it possesses enormous institutional structures without the capability to translate this into legitimate command of obedience. Indeed, the case is made that in spite of the enormous structural strength of the state in Africa, it suffers a glaring inability to exercise meaningful rule over its society; the state in Africa relates in a predatory sense to the society, which, in turn, treats the state with disdain. The spectacle of a state without meaningful control over its society is what prompted Jackson and Roseburg (cited in Bratton, 1989) regard the state in Africa as one with a juridical existence, which existence is based not on internal validation but on the willingness of other states and the international system to recognize it and prop it up. A state with juridical existence, however, in spite of the name attached to it, cannot be presented as a functional state. For while international recognition is! important to the existence of state, it is essentially defined first by its

Sovereign mastery and control over its territory and the attendant internal dynamics. Where the control over the internal dynamics is absent, it is difficult to affirm the existence of a state even if the international system thinks otherwise. The absence of control over the internal dynamics of a territory by a so-called state makes such a nonfunctional entity given that the so-called state is lacking in the performance of the key function of exercising reasonable control over its society and territory.

Perhaps drawing from the implication of the juridical existence of the state in Africa, Clapham (1996) insisted that the African state is essentially a 'quasi-state' - one that cannot meet the demands of 'empirical statehood' in the sense that it does not have the capacity to exercise effective power within its territory. In the same vein, Ake (1996) argued that in Africa, 'there is ... strictly speaking, no state, there is only a contested terrain ... in most of Africa, there is no state in the proper sense ...'. This means that the abiding image of what exists as the state in Africa is a non-functional entity that is invested with the name but is unable to effectively exercise the duties and responsibilities of the state beyond the use of forced.

The reality of the existence of the state in Africa, therefore, is not just about a deformed, deficient, weak, inchoate and ineffectually institutionalized entity, but that of one in need of real existence and, by that token, real establishment. The implication of a state that is lacking in real institutionalization and which is ineffectual in its existence in Africa is the ${ }^{\wedge}$ ' need to bring the state into functional existence. This is to state that they reality of the nature of the African state is that of a non-functional entity, requiring transformation and efforts to bring it into functional and real existence. Needless to add that it is only a functional state, which state is 
sorely lacking in Africa today, that would affirm the real existence of the state in Africa.

\section{The State and Democratic Transition in Africa}

Given the argument that the state is a necessary platform for democracy, it is not surprising that democratic transition has been largely characterized by hiccups rather than success. And this is without prejudice to the internal strengths and weaknesses of specific democratic transition programmes in different locations in Africa. For in spite of the differences in the approaches of these programmes, it is not impossible to isolate general tendencies that are applicable to most of them. And one of these general tendencies has been the limited success of the democratization agenda in bringing about the expected improvements in the material and other aspects of the lives of the people. This is against the background of the argument that democratization in Africa has been reduced to 'the introduction of elections and multipartyism' even as it is realized that real democracy goes beyond these to the fulfillment of the people's basic human needs.

The point, however, is that this limited success of democratic transition in Africa is not unexpected given the fact that democratization programmes in Africa significantly do not include the positive transformation of the state within their processes. Ake (1996:6) called attention to democratization in Africa being 'conducted with no questions asked about the character of the state as if it has no implication for democracy'. This is to state that the democratization process has not been sensitive to the reality of the absence of a functional state within the African terrain. Rather than being concerned with the nature and character of the state, the democratization process has been bogged down by the rudiments of the conduct of elections and the establishment of as many as possible political parties. It is as if with elections, the people are guaranteed control over their own affairs and would be in a position that governments serve their needs. The reality on the ground in Africa, however, has been that the so-called elections 'give the voter only a choice between oppressors', resulting in 'voting that never amounts to choosing' to the extent that elections 'can be manipulated through rules of the game that reduce the chances for fairness and by electoral fraud'. This is one reason why the manipulation of elections has been rampant in the democratization process in Africa, leading to disputed elections in Cote d'lvoire, Liberia, Sierra Leone and Nigeria, with these serving as basis for further disputes and ultimately violent conflicts, if not war. It is needless to state that the needs of the people are further compromised in the avoidable conflicts- engendered by disputed elections.

This is not, however, to dismiss the importance of elections 01 argue that electoral democracy does not have its own place in the democratization scheme. Indeed, it has been contended that electoral democracy is an important starting point for democratization in Africa because: 
The legality of the political opposition, enlargement of the public space through a plural press and a rich array of civic organizations (and) gradual abandonment of undue persecution of conscientious objectors, etc. are important preconditions for the more elaborate, more arduous and longterm of reconstituting and transforming the political... institutions and political cultures (Amuwo, 1999: 16).

The argument here is that rather than being blind to the character of the state in Africa, democratic transition in Africa purposively craves electoral democracy in order to start a process that would ultimately see to the needed transformation of the state while also ensuring material benefits for the people. Reduced to its essentials, democratization in Africa, within this argument, is expected to use electoral democracy to achieve transformation of the state in Africa.

But, evidently, this argument does not reckon with the unique placement of the state as the highest form of organization in society with the overarching powers over all other structures and organizations. For this unique placement already assures that every activity takes place within the context defined by the state, such that the so-called electoral democracy would have to contend with the reality of the definitive antidemocratic existence of the state. And this is visible in the sense that the existing chasm between the state and the people in Africa reflecting in their antipathy to government and its activities including elections ensure that the people are not available to help maintain or insist on the integrity of the electoral process. With the people divorced from the electoral process largely due to the existing chasm between the state and the society occasioned by the subsisting character of the state, is it any surprise, according to Oyediran (1990:103), that elections in Africa, including those conducted as part of the on-going electoral democracy, 'have been a recurring source of disputes, strong arm tactics, crisis and conflict'? given that the context for politics, including electoral democracy, is provided by the state, which context in the African setting is essentially anti-people, anti - their desire to control governments and anti-democracy, it ought to be clear that the optimism infused into the workings of electoral democracy in Africa is not well founded. Since that state is first-order importance in the workings of political processes, it is difficult to see how it is meant to be transformed through electoral democracy that is, in itself, conditioned ${ }^{1}$ by the state and which, in its own conception, does not address or take into account the debilitating character of the state.

The importance of the state within the democratization process becomes of real value in the African setting given the argument that there is a reality of the absence of the state in a functional sense within the setting. The scenario of a setting without the existence of a functional state is such that presents no viable context for democracy since democracy is expected to function within the parameters of the state. The idea of democracy, as argued, already assumes the existence of the state, such that where the state 
is not functionally in existence, the desire to enthrone democracy becomes a pipe dream unless it starts with the efforts to establish a functional state. The non-realization of this essence in the democratization efforts in Africa has meant that such efforts are frustrated by the activities of a non-functional state which propensity for force ensures that it imposes its will to upset the due processes that should be the hallmark of the democratization process. This is why arbitrary exercise of power continues to be the mainstay of governments in Africa in spite of the democratization efforts ${ }^{\wedge}$ The scenario in Africa is simply that of trying to build something on nothing, which strategy is bound to produce failure, no matter the sincerity of the intention and the quality of the efforts put into the process. There is no building of democracy in Africa without the platform of a functional state; democracy is not realizable to the extent that the state continues to have a non-functional existence in Africa.

Obviously, the reality of a state without functional existence presents a major obstacle to any meaningful democratic transition in Africa. And a starting point to addressing this issue is to acknowledge its reality. It is not going to be enough to pretend that the problem of the state "would be addressed after a successful democratic transition as the reality has shown that democratic transition itself would not be met with success without a favourable context provided by the state. Democratic transition, therefore, has to substantially include within its processes the need to establish as functional state if it is to be meaningful. Whereas what is often suggested is the transformation of the state to serve the interests and needs of the people through the instrumentalities of electoral democracy, but the reality is that it is only what exists that would be amenable to transformation, such that in the absence of a functional state in Africa, the needed transformation has to start with the real, functional establishment of the state. Meaningful democratization in Africa, therefore, has to entail, as a first order principle, the establishment of the functional state to provide a viable context for the establishment of real democracy.

The argument here is that the state is more than the existence of a handful of institutions and structures that are functioning haphazardly and relating on the basis of force to the society. Rather a real state has to be effective in the task of administering rules, regulations and relations within its territory, such that a state becomes a nonfunctional one where it is unable to effectively perform this task. Unfortunately, this is the condition of the state in Africa and it is this non-functional state that has been shown to have a disruptive influence on the on-going democratic transition in Africa, frustrating the realization of the true goals of democratic rule. It then means that one way of transcending the present limited success of the democratization efforts in Africa is to ensure the establishment of the state to serve as basis for meaningful democratization. This way, the state, in the words of Nzongola-Ntalaja and Lee (1997) 'becomes an ally rather than an obstacle on the democratization process'. It is important to stress that only a functional state can serve as ally in this, regard. 


\section{Conclusion}

This paper has attempted to deepen the existing understanding of the relationship between the state and democracy in Africa against the background of the persisting unsavory existence of the state in Africa and the limited success of the democratization efforts. The argument here is based on the notion that the state is a specific historical construct, which is distinguished by its guarantee of the individual as a social role through its provision for the equal subjection of all members of the society to the sovereign. This distinguishing characteristic of the state makes it a prime facilitator of democracy, as democracy is inconceivable outside the notion of the individual as a social role, which supplies the equality basis for democratic rule. A deep and direct relationship between the state and democracy is thus advanced to the extent that the individual identity provided by the state is one important building block for democracy.

This abiding relationship between the state and democracy serves as the backdrop to the enunciation of a major obstacle in the path of democratic transition in Africa visible in the absence of a functional state within the African terrain. While the existence of the state in Africa is not entirely denied, the fact that what passes for the state is not in a position to exercise reasonable and effective administration and control over its territory - which is a key requirement in the functioning of a state - is used to justify the depiction of the state in Africa as that of a non-functional existence. The prosecution of a democratization agenda within the context of the absence of a functional state is thus presented as a major disincentive to democratization as a viable context for democracy is missing in the absence of a functional state. It is argued that the present limited success of the democratization process in Africa is not unrelated to the frustration engendered by the existence of a state that in its non-functional essence operates in an antidemocratic and anti-people manner, suggesting the need for democratic transition in Africa to concretely grapple with the task of overcoming the debilitating context provided by the non-functional state if it is to be meaningful and fully realize its goals. It is thus advanced that meaningful democratic transition in Africa has to incorporate the functional establishment of the state as a first order principle to the extent that democracy is not realizable outside the context of the state and the tendency of a non-functional state to frustrate democratization efforts.

While stating the requirement for the establishment of a functional state in Africa as a necessary and starting part of a worthwhile democratization process is a positive movement toward the full realization of the goals of democratic transition, the attainment of this requirement presents its own complexity in grappling with the precise manner in which the establishment of a functional state is to be undertaken or made a composite part of the democratization agenda. In this regard, the full enunciation of the parameters for the realization of this goal is beyond the purview of this paper as it obviously requires further research and analyses. 
Nonetheless, the point has to be made that this is a very important task to the extent that no meaningful democracy can be built outside the context of a functional state. It then means that every effort required should be devoted to realizing this goal no matter the complexity it presents. Indeed, overcoming the complexity of establishing a functional state in Africa to provide a viable context for democratization should be of utmost concern if the desire for successful democratic transition in Africa is to be realized.

\section{References}

Ake, Claude (1996) Is Africa Democratizing?, Lagos: Centre for Advanced Social Sciences (CASS) and Malthouse Press Limited.

Amuwo, Kunle (1999) "Rethinking the Linkage between the Market and Democracy Africa", Nigerian Journal of Social and Management Sciences, Volume 2, Number 1, Ago-Iwoye.

Bayart, J., et al. (1999) The Criminalisation of the State in Africa, Indiana: Indiana University Press.

Bratton, Michael, (1989) "Beyond the State: Civil Society and Associational Life in Africa", World Politics, 41(3).

Callaghy, Thomas N. (1988), “ The State and the Development of Capitalism in Africa: Theoretical, Historical and Comparative Reflections", Donald Rothchild and Naomi Chazan, (eds), The. Precarious Balance: State and Society in Africa, Boulder: Westview Press.

Clapham, Christopher (1996), Africa and the International System: the Politics of State Survival, New York: Cambridge University Press. Frankel, Boris (1983)

Beyond the State? Dominant Theories and Socialist Strategies, London: Macmillan Press Limited.

Nzongola-Ntalaja, G. and Lee, Margaret C. (eds.), (1997), The State and Democracy in Africa, Harare: AAPS Books.

Nzogola-Ntalaja, Georges (1997) "The State and Democracy in Africa", Georges Nzongola-Ntalaja and Margaret C. Lee, (eds.), The State and Democracy in Africa, Harare: AAPS Books.

Oyediran, Oyeleye (1990) "Here We Are, and Where We Go From Here? The Past, Present and Future of Elections in Nigeria", L. Adele Jinadu and Tony Edoh, (eds.),. The 1987-88 Local Government Elections in Nigeria, Volume 1, Case'Studies* Lagos: National Electoral Commission (NEC).

Poggi, Gianfranco (1978) The Development of the Modern State, London: Hutehinson and Company Limited.

Siedentop, Larry (1983) "Political Theory and Ideology: The Case of the State", David Miller and Larry Diedentop, (eds.), The Nature of Political Theory, Oxford: Clarendon Press. 